\title{
Isolation and characterization of Rhizobium sp. from a collar rot tolerant groundnut (Arachis hypogaea L.) variety
}

\author{
Shalvi Pandey \& Dipjyoti Chakraborty ${ }^{*}$ \\ Department of Bioscience and Biotechnolgy, Banasthali Vidyapith, Rajsthan 304 022, India
}

\section{Article history}

Received: 01 December 2019

Accepted: 30 December 2019

Published: 31 December 2019

\section{Publisher}

Horizon e-Publishing Group

\section{*Correspondence}

Dipjyoti Chakraborty

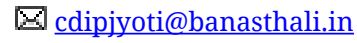

\begin{abstract}
Groundnut, a major pulse crop, is prone to fungal diseases especially collar rot at seed germination and early seedling stage. In the present study, symbiotic bacteria was isolated and characterised from a collar rot resistant groundnut variety, Mallika and identified as Rhizobium pongamiae following biochemical and molecular characterization (NCBI Acc. No. MK770416). The bacterial isolate on cross inoculation, may be useful in improving crop productivity and enhancing collar rot disease tolerance in susceptible crops.
\end{abstract}

Keywords: Arachis hypogaea; Aspergillus niger; collar rot; crop legume; Rhizobium pongamiae

Citation: Pandey S, Chakraborty D. Isolation and characterization of Rhizobium sp. from a collar rot tolerant groundnut (Arachis hypogaea L.) variety. Plant Science Today 2019;6(sp1):631-634. https://doi.org/10.14719/pst.2019.6.sp1.693

Copyright: ( ) Pandey \& Chakraborty (2019). This is an open-access article distributed under the terms of the Creative Commons Attribution License, which permits unrestricted use, distribution, and reproduction in any medium, provided the original author and source are credited (https://creativecommons.org/licenses/by/4.0/).

Indexing: Plant Science Today is covered by Scopus, Web of Science, BIOSIS Previews, ESCI, CAS, AGRIS, UGC-CARE, CABI, Google Scholar, etc. Full list at http://www.plantsciencetoday.online

\section{Introduction}

Groundnut belonging to Fabaceae family (earlier Leguminosae), is commonly known as peanut, monkey nut or goober. It is an important crop for the tropical and sub-tropical regions. Groundnut, as a major pulse crop, plays an important role in Indian economy and is also grown as an oil seed crop (1). Groundnut seeds contain $22-30 \%$ of protein and almost $44-56 \%$ of oil. Approximately 9.5-19\% carbohydrates and different types of minerals such as $\mathrm{Mg}, \mathrm{K}, \mathrm{Ca}, \mathrm{P}$ and vitamins (K, E and B group) are also present in groundnut seeds (2).

Nowadays, for the higher yields of crops, agriculture community highly depends on the different types of pesticides and agro-chemicals (3,
4). These harmful agro-chemicals causes various problems including health issues, environmental pollution, and disturbance in biological communities etc. As an alternative, symbiotic rhizobacteria have the ability to fix the atmospheric nitrogen, improve soil fertility and can increase productivity of legume crops like groundnut when used as inoculants (5). Bio-fertilizers are capable to enhance the soil quality, provide protection to the plants from the different types of stresses either biotic or abiotic (6). Collar rot disease in groundnut is a serious issue, the causal organism being Aspergillus niger. Different types of soil factors and environmental factors also facilitate this disease.

The present study focused on the isolation and characterization of Rhizobium sp. from a collar 
rot resistance groundnut variety (Mallika) which may suppress or inhibit $A$. niger when cross inoculated on collar rot susceptible cultivars.

\section{Materials and Methods}

\section{Plant material}

The plants of Arachis hypogaea cv. Mallika (ICHG00440) were collected from the Krishi Vigyan Kendra, Banasthali Vidyapith, Rajasthan.

\section{Root nodule collection and microbial isolation}

Nodules collected from roots were thoroughly washed with tap water. For the surface sterilization, nodules dipped were momentarily in $95 \%$ ethanol, washed and dipped in sodium hypo-chloride solution for 1-2 min and after that again washed thoroughly with autoclaved water. Root nodules were crushed in minimum amount of sterile water and streaked on petri plates containing Yeast Extract Mannitol Agar (YEMA) medium (7).

\section{Biochemical characterization}

\section{Congo red test}

YEMA media plates were prepared by adding Congo red dye (10 $\mathrm{ml}$ of $0.25 \%)$. Bacterial strain was streaked on it and incubated at $28 \pm 2{ }^{\circ} \mathrm{C}$ (8).

\section{Bromothymol blue test}

YEMA media plates were prepared containing BTB dye (5 ml of $0.50 \%$ ), bacterial isolate was streaked on it and incubated at $28 \pm 2{ }^{\circ} \mathrm{C}$ (8).

\section{Alfa-ketolactose test}

The bacterial isolate was streaked on lactose medium and incubated at $28 \pm 2{ }^{\circ} \mathrm{C}$ for 5 to 7 days. Benedict solution was poured over the medium with bacterial culture and kept at room temperature for $2 \mathrm{~h}(9)$.

\section{Catalase test}

Catalase activity was observed by the following method of McLeod and Gordon, 1923. Bacterial colonies were picked in inoculation loop and dipped in hydrogen peroxide. Appearance of water bubbles within 5-8 sec confirms oxygen evolution by bacteria (10).

\section{Indole test}

Production of indole acetic acid was observed in inoculated tryptophan broth $(2 \mathrm{~g} / \mathrm{l})$. After 7 days of incubation (at $30{ }^{\circ} \mathrm{C}$ ), Kovac's reagent $(1 \mathrm{ml})$ was added to the bacterial culture taken in a test tube and observed for 10-15 min for colored ring formation (11).

\section{HCN production}

Nutrient Agar plate was prepared containing 4.4 $\mathrm{g} / \mathrm{l}$ glycine and the selected bacterial strain was streaked on it. After that, sterile filter paper which was dipped in picric acid and sodium carbonate solution was kept over the inoculated region. Plate was incubated for $2-5$ days at $30{ }^{\circ} \mathrm{C}$. Formation of pale yellow color indicates low HCN production and dark brown color indicates high HCN production (8).

\section{Molecular characterization}

The bacterial DNA was isolated by using GenElute Bacterial Genomic DNA Kit (Sigma, catalogue number- NA2110-1KT). PCR amplification was done with the help of universal 16S rRNA gene primers fdl (AGAGTTTGATCCTGGCTCAG) and rd1 (AAGGAGGTGATCCAGCC) (12). The 16s rRNA gene primer set, 63f (5'-AGGCCTAACACATGCAAGTC-3') and Rhiz-1244r (5'-CTCGCTGCCCACTGTCAC-3') specific to Rhizobium sp. was also used (13). To design the primers, the conserved regions of the 16S rRNA genes are used and are capable of amplifying nearly full-length $16 S$ rDNA.

\section{Results and Discussion}

Isolation and morphological identification of isolated strains

Fourteen bacterial isolates were obtained from $A$. hypogaea, out of which only one strain showed morphological similarity to the Rhizobium sp. as mentioned in the Bergey's Manual. The bacterial colony was fast growing, translucent, rod-shaped, mucoid and aerobic in nature. The colony was convex and 2-3 $\mathrm{mm}$ in diameter.

\section{Biochemical characterization}

\section{Congo red test}

Congo red test was done to check the purity of isolated Rhizobium sp. as different strains have variable ability to retain the dye as compared to the other bacteria. The bacterial isolate grown on YEMA medium in dark did not retain the dye (Fig. 1A).

\section{Bromothymol test}

Growth rate of the isolated bacterial strain was observed. A color change in dye denoted the growth rate among the studied isolates. Fast growing isolates turn dye color from green to yellow and on the other hand slow growing isolates change the dye color from green to yellow. In this study, the isolated Rhizobium sp. was fast growing as it turned dye color from green to yellow (Fig. 1B).

\section{Alfa-ketolactose test}

Benedict reagent was used in this test. Agrobacterium sp. can change the Benedict Reagent's color form blue to yellow but the isolated Rhizobium sp. did not change the color (Fig. 1C).

\section{Catalase test}

$3 \%$ hydrogen peroxide was used and when it came in contact with isolated Rhizobium sp. 

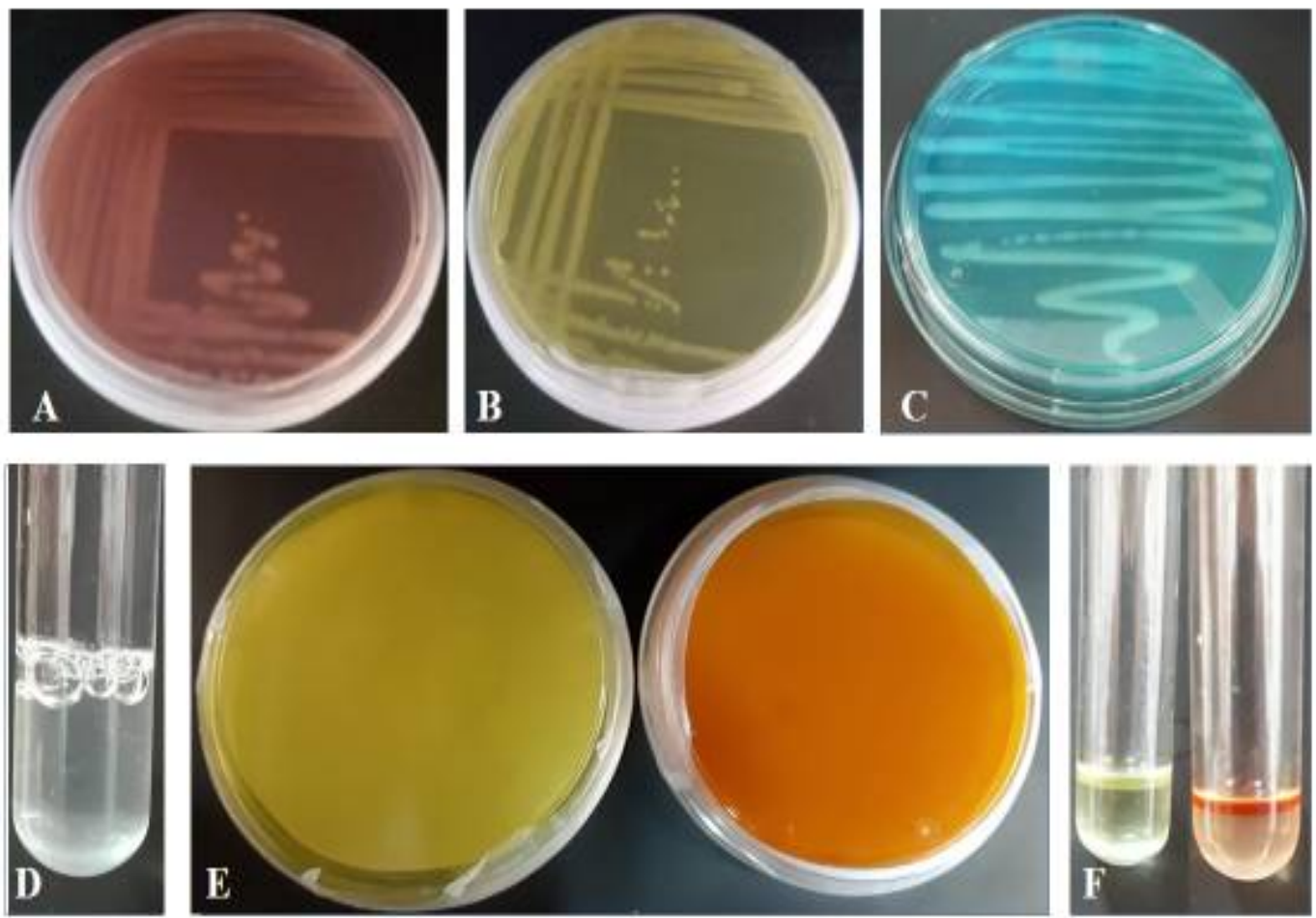

Fig 1. Biochemical Characterization of isolated Rhizobium strain (A) Congo red test; (B) Bromothymol test; (C) Alfa-ketolactose test; (D) Catalase test; (E) HCN production; (F) Indole test.

culture, bubble formation occurred. This result show that the isolated Rhizobium sp. is aerobic in nature (Fig. 1D).

\section{HCN production}

The inoculated Rhizobium sp. changed the color from pale yellow to dark brown show the positive result for HCN production (Fig. 1E).

\section{Indole test}

A red color ring was formed after the addition of Kovac's Reagent which showed the positive result for high IAA production (Fig. 1F).

\section{Molecular characterization}

Universal 16S rRNA gene primers fd1, rd1 and Rhizobium specific 16S rRNA gene primers (63f and 1244) were used for PCR amplification were by $1.67 \mathrm{kbp}$ and $1.4 \mathrm{kbp}$ bands were obtained respectively. DNA sequencing was done and EZ Taxon Tool was used to analyse the obtained $16 \mathrm{~s}$ rRNA gene sequence and the isolate was identified as Rhizobium pongamiae strain BVAH25 and submitted to NCBI (Acc. No. MK770416).

\section{Conclusion}

Biotic and abiotic stresses have ability to suppress the growth and adversely affects the productivity of the leguminous plants. Symbiotic interaction between legume plant roots and microorganisms enhance the defence mechanism against these stresses and cross inoculation of selected strains can be used for this purpose (14-16). In the present study, a bacterial isolate was characterised from the root nodules of Arachis hypogaea cv. Mallika and identified on the basis of morphological and molecular characteristics. The isolated Rhizobium pongamiae may promote growth and increase tolerance to different types of stresses and also play an important part in sustainable agriculture system.

\section{Competing interest}

The authors declare that they have no competing interest.

\section{Author's contributions}

SP performed the experiments, designed the manuscript with the collection of references. DC conceptualised the work edited the manuscript.

\section{Acknowledgements}

The authors are grateful to Prof. Aditya Shastri, Vice Chancellor, Banasthali Vidyapith for providing all necessary support. We acknowledge the Bioinformatics Center, Banasthali Vidyapith supported by DBT for providing computation support, and DST for providing networking and equipment support through the FIST and CURIE programmes at the Department of Bioscience and Biotechnology. CESME, Banasthali Vidyapith, supported by MHRD, Government of India under the PMMMNMTT is acknowledged for organizing the symposium. 


\section{References}

1. Sharma P, Kumar Saini M, Deep S, Kumar V. Biological control of groundnut root rot in farmer's field. J Agric Sci. 2012;4(8). https://doi.org/10.5539/jas.v4n8p48

2. Ayoola PB, Adeyeye A, Onawumi Oo. Chemical evaluation of food value of groundnut (Arachis hypogaea) seeds. Am J Food Nutr. 2012;2(3):55-57. https://doi.org/10.5251/ajfn.2012.2.3.55.57

3. Hayat R, Ahmed I, Sheirdil RA. An overview of plant growth promoting rhizobacteria (PGPR) for sustainable agriculture. In: Ashraf M, Öztürk M, Ahmad M, Aksoy A (eds) Crop Production for Agricultural Improvement. Springer, Dordrecht; 2012, pp. 557-79. https://doi.org/10.1007/978-94-007-4116-4 22

4. Gajera HP, Vakharia DN. Production of lytic enzymes by Trichoderma isolates during in vitro antagonism with Aspergillus niger, the causal agent of collar rot of peanut. Braz J Microbiol. 2012;43:43-52. https://doi.org/10.1590/S1517-83822012000100005

5. Datta A, Singh RK, Kumar S. Isolation, characterization and growth of Rhizobium strains under optimum conditions for effective biofertilizer production. Int J Pharm Sci Rev Res. 2015;32(1):199-208. ISSN 0976 - 044X.

6. Mosharof HAKM, Musharraf HM, Hakim MA, Islam MM, Jannatul F. Isolation and selection of Bradyrhizobium from the root nodules of indigo plants (Indigofera tinctoria L.). Afr J Biotechnol. 2012;11(58):12183-91. https://doi.org/10.5897/AJB12.1288

7. Pawar VA, Pawar PR, Bhosale AM, Chavan SV. Effect of Rhizobium on seed germination and growth of plants. J Acad In Res. 2014;3(2):84-88. ISSN: 2278-5213.

8. Saraf R, Chaudhary S, Chakraborty D. Isolation and characterization of osmotolerant Rhizobium sp. from Vigna mungo (L.) Hepper grown in semi-arid region.
Vegetos.

2018;31:102-07. https://doi.org/10.5958/2229-4473.2018.00039.3

9. Bernaerts MJ, Deley J. A biochemical test for crown gall bacteria. Nature. https://doi.org/10.1038/197406b0

1963;197:406-07.

10. Kamal J, Bano A. Potential allelopathic effects of sunflowers on microorganisms. Afr J Biotechnol. 2008;7(22):4208-11. https://doi.org/10.5897/AJB08.837

11. Gachande BD, Khansole GS. Morphological, cultural and biochemical characteristics of Rhizobium japonicum and Bradyrhizobium japoicum of soybean. Biosci Discov. 2011; 2:1-4. ISSN 2229-3469.

12. Weisburg WG, Barns SM, Pelletie DA, Lane DJ. 16S rDNA amplification for phylogenetic study. J Bacteriol. 1991; 173:697-703. https://doi.org/10.1128/jb.173.2.697-703.1991

13. Singh BK, Nazaries L, Munro S, Anderson IC, Campbell CD. Use of multiplex terminal restriction fragment length polymorphism for rapid and simultaneous analysis of different components of the soil microbial community. Appl Environ Microbiol. 2006;72:7278-85. https://doi.org/10.1128/AEM.00510-06

14. Kumari D, Chakraborty D. Drought stress mitigation in Vigna radiata by the application of root-nodulating bacteria. Plant Sci Today. 2017;4(4);209-12. https://doi.org/10.14719/pst.2017.4.4.343

15. Pandey S, Ror S, Chakraborty, D. Analysis of Biochemical Responses in Vigna mungo varieties subjected to drought stress and possible amelioration. Int J Sci Resh Agric Sci. 2014;1:6-15.https://doi.org/10.12983/ijsras-2014-p0006-0015

16. Chaudhary S, Chakraborty D. Cross inoculation with beneficial Rhizobium strain promotes plant growth in Vigna mungo. Vegetos. 2019;32(2):223. https://doi.org/10.1007/s42535-019-00026-3 